\title{
Corporate Governance and Dividend Policy in the Banking Sector on the Indonesian Stock Exchange
}

\author{
Muhamad Umar Mai ${ }^{*}$, Mochamad Edman Syarief ${ }^{2}$ \\ 1,2Department of Accounting, Bandung State Polytechnic, Indonesia \\ ${ }^{*}$ Corresponding Author: umar.mai@polban.ac.id
}

\begin{abstract}
This study is aimed at exploring the impact of corporate governance on dividend policy. The study was undertaken on the banking sector indexed in Indonesian Stock Exchange from 2009 to 2019. The method of data analysis used logistic regression and ordinary least squares regression. The findings demonstrated that four of five criteria of Corporate Governance had a major impact on dividend policy, such as propensity to pay dividends and dividend pay-out ratio. Institutional ownership, board of directors' size and audit committee size have a positive influence on propensity to pay dividends while the female board of directors has a negative effect. This study did not show that independent board of commissioners had a substantial impact on the propensity to pay dividends and dividend pay-out ratio. The findings of this research contribute to the financial literature, in particular the relationship between corporate governance and dividend policy. These findings should be properly taken for consideration among investors when making decisions on their investments.
\end{abstract}

Keywords : Corporate governance, dividends policy and banking sector. JEL Classification : G21, G32

\section{INTRODUCTION}

Dividend policy is one of the topics that gain the most controversy till now. Financial academics are very involved in the discourse of dividend policy which offers extensive theoretical modeling and ongoing empirical research (Al-Najjar \& Kilincarslan, 2019). Even though research on dividend policy has been extensively studied, it is difficult to grasp an understanding of factors that influence dividend policy and the relationship between these variables (Rajput \& Jhunjhunwala, 2019). Over 40 years ago, Black (1976) suggested that the more focused we pay attention to the image of dividend, the more it looks like a puzzle whose pieces are different. Even though Black (1976) had come to such a conclusion over 40 years ago, his statement remains true, evidences, and theories of dividend policy have not been developed yet. 
In some prior studies, multiple models have been developed and empirically tested to understand why companies pay dividends (for example, Gruber, 1970; Brennan, 1970; Rozeff, 1982). A group of researchers has surveyed factors affecting dividend-relate decisions by the corporate manager (for example, Jabbouri, 2016; Kent Baker, Kilincarslan, \& Arsal, 2018). Many researchers have investigated investors to learn their perspectives on dividends (For example, Baker \& Jabbouri, 2017; Baker, Kapoor, \& Jabbouri, 2018). Several studies even investigated specific company attributes as determinants of dividend policy (For example, Ranajee, Pathak, \& Saxena, 2018; Singla \& Samanta, 2019; Budagaga, 2020). Other studies tested a model life cycle empirically to understand why companies pay dividends. (For example, Flavin \& O'Connor, 2017; Trihermanto \& Nainggolan, 2018; Meza, Báez, Rodriguez, \& Toledo, 2020). However, despite extensive research and discussion, the company's real motivation to pay dividends remains unanswered (AlNajjar \& Kilincarslan, 2019).

An agency theory implied that managers likely exploited a company's resources for their own benefits, not to support company owners (Jensen, 1986). Dividends would serve as a corporate governance mechanism to resolve agency problems between managers and shareholders. (Jensen, 1986). Firth, Gao, Shen, \& Zhang (2016) stated that paying larger dividends to shareholders reduced the scale of agency conflicts. Moreover, another function of agency control through dividend payments was alleviating the severity of conflict between managers and shareholders (See, Bilel, 2020). Therefore several studies explored the effects of corporate governance mechanisms on dividend policy (For example, Shamsabadi, Min, \& Chung, 2016; Kulathunga, Weerasinghe, \& Jayarathne, 2017; Atanassov \& Mandell, 2018). Up to now, there have been a lot of studies that examined the relationship between corporate governance and dividend policy, but the results of the research were still mixed. On another side, Rajput \& Jhunjhunwala (2019) demonstrated that corporate governance had a positive and important effect on dividend payment decisions and a major determinant of dividend payout rate. Pahi \& Yadav (2019) claimed that companies with better corporate governance tend to pay higher dividends. On the other hand; Sanan (2019) concluded that there was a tendency for companies with better corporate governance to pay lower dividends. Atanassov \& Mandell (2018) argued that poorer governance firms tend to pay larger cash dividends than better ones. Imamah, Lin, Suhadak, Handayani, \& Hung (2019) argued that institutional ownership of companies implementing Sharia law in Indonesia played a very important role in corporate governance. It is proven with a negative correlation between institutional ownership and dividend payments in case of fast business growth; however, there was a positive correlation between institutional ownership and dividend payments during low business growth.

This paper addressed the effects of corporate governance on dividend policies in the banking sector listed on the Indonesia Stock Exchange. This study contributed to the literature on corporate dividends thorough knowledge of the role of corporate governance proxied by institutional ownership, a board of directors size, female board of directors, independent board of commissioners, and audit committee size on dividend policy. The dividend policy, in this paper, dealt with bank preference to pay dividends and to determine the dividend payout ratio. This research further offers insight for investors and potential investors in recognizing corporate governance and its impact on dividend policies. Sections in this paper were arranged as follows: literature review, 
hypothesis development, followed by an explanation of the research method, discussion of research findings, and concluded with conclusion and implications.

\section{HYPOTHESES DEVELOPMENT}

Institutional investors played an important role in corporate governance and particularly related to reducing agency costs (Mehdi, Sahut, \& Teulon, 2017). Cheng, Lin, \& Tung (2018) argued that the more institutional investors raised their stakes, the more influential their role was in corporate monitoring and governance, including dividend payout policy in particular. In previous studies, however, the correlation between institutional ownership and dividend policy was investigated with mixed results. For example, Balachandran, Khan, Mather, \& Theobald (2019) claimed that companies with higher international institutions were less likely to pay dividends and have lower payout ratios. Chang, Kang, \& Li (2016) argued that companies with long-term institutional investors played a monitoring role using dividend payments as a monitoring tool. Firth et al. (2016) revealed that external shareholders likely paid larger dividends to reduce the insider-regulated free cash flow. Furthermore, they assumed that some financial investors, such as banks, insurance companies, and securities companies had no impact on cash dividend payments. The relationship between institutional ownership and dividend payment was demonstrated in three research findings. First, a study by Mehdi et al. (2017) used a sample of 362 non-financial companies registered in the East Asian and Gulf Cooperation Council countries for the period 2003-2011. They concluded that dividend payout decisions with institutional ownership and board activity would increase. Second, for the period 2001 to 2010 Cheng et al. (2018) analyzed a sample of 9,219 from 1,206 companies listed on the Taiwan Stock Exchange. They argued that stable institutional investors likely influenced managers to pay cash dividends rather than investing in inefficient projects. Third, for the years 2007-2013, study carried out by Basri (2019) involved 15 state-owned firms indexed in the Indonesian stock exchange. They concluded that institutional ownership had a negative influence on dividend policy. There was inconsistent evidence in some literature on institutional ownership and dividends policy. However, this study aims to predict whether larger institutional ownership is more likely to pay dividends with a larger payout ratio. Therefore, the proposed hypotheses are the following:

H1a: Institutional ownership has a positive effect on propensity to pay dividends. H1b: Institutional ownership has a positive effect on the dividend pay-out ratio.

There is an ongoing discussion of the notion that the Board attributes may impact the payment of dividends (Byoun, Chang, \& Kim, 2016; Pahi \& Yadav, 2019). the board attributes such as board diversity, the board size, board tenure, board member age, board independence, and CEO duality were analyzed as background attributes of the board of directors (Tahir, Masri, \& Rahman, 2020). Studies of the relationship between board size (one of the board of directors' attributes) and policy on dividends showed various outcomes. Research by Tahir et al. (2020) on Malaysian non-financial firms from various industries from 2005 to 2018 showed a positive effect of the board size on dividend policy. A study from Elmagrhi et al. (2017) indicated that the Board size had a positive influence on the dividend payout ratio with samples of SMEs listed in the UK Alternative Investment Market for the period of 2010-2013. A study by Mehdi et al. (2017) in 20032011 with a sample of 362 companies from four East Asian countries (Malaysia, Thailand, 
Taiwan, Indonesia) and four GCC countries (Bahrain, Saudi Arabia, Kuwait, and Oman) has demonstrated that Dividend decision-making in the financial crisis is inversely proportional to the size of the board of directors. For the period 2013 to 2016, A study by Sanan (2019), which used a survey of 118 Indian companies representing different sectors, found that the board size had a negative impact on dividend payment policies. In the literature on the relationship between board size and dividend policy, inconsistent findings were revealed. This research, however, predicts that banks with greater board sizes pay more dividends and payout ratios. Therefore, the proposed hypotheses are as follow:

H2a: The board of directors' size has a positive effect on the propensity to pay dividends. $\mathrm{H} 2 \mathrm{~b}$ : The board of directors' size has a positive effect on the dividend pay-out ratio.

The accountability of the board of directors for important business decision-making, such as dividend policy and decision effectiveness, depends on the characteristics of the board (Chen, Leung, \& Goergen, 2017). Recently stakeholders have emphasized gender diversity on company boards of directors, and empirical evidence suggesting that gender diversity will impact the effectiveness of the board (Gyapong, Ahmed, Ntim, \& Nadeem, 2019). However, in India, Russia, and China, Saeed \& Sameer (2017) found a negative relationship between dividend payments and gender diversity. Meanwhile, McGuinness, Lam, \& Vieito (2015) suggested that the ratio of female board members and the dividend payments in China were not significantly correlated. On the other hand, PuchetaMartínez \& Bel-Oms (2016) stated that the correlation between board gender diversity and dividend payments in Spain was positive. A recent study by Benjamin \& Biswas (2019) using Bloomberg's 2010-2015 company data from S\&P 1500 revealed a relationship between female board directors and dividend payments. They demonstrated that gender diversity in the board has good and positive impacts on dividend payments and dividend payout rates. A study by Almeida, Morais, \& Coelho (2020) on non-financial companies in the Brazilian Stock Exchange for the period 2010-2015 shows that the proportion of women in the executive board has a marginal effect on company dividend policies. For the period 2013-2016, Sanan (2019) conducted a survey of 118 Indian companies and found that female directors on the board had a negative and significant effect on dividend payments. There are inconsistent findings of the relationship between female board directors and dividend policies in literature. However, this paper proposed a hypothesis that banks with a larger proportion of female directors likely pay small dividends and low payout ratios.

Therefore, the formula of hypotheses as follows:

H3a: Female board of directors has a negative effect on the propensity to pay dividends. $\mathrm{H} 3 \mathrm{~b}$ : Female board of directors has a negative effect on the dividend pay-out ratio.

Rajput \& Jhunjhunwala (2019) argued that the pressure of regulatory and legislative bodies on corporations to improve the independence of the Board for Good Governance was increased to protect the rights of shareholders. The Independent Board in Indonesia is appointed to the board of commissioners, according to Regulation No 33/POJK.04/2014 of the Financial Services Authority. One of the requirements of the Financial Services Authority is that at least 30\% of the total members of the Commissioners board must be independent Commissioners. The minimum criterion of $30 \%$ is intended to improve the company's performance. However, several studies on the impact of board independence on dividend payout policies have shown contradictory 
findings. Research on Turkish firms listed on the 2006-2014's Istanbul stock exchange index by Sener \& Akben Selcuk in 2019 has shown the negative influence of independent boards on dividend policy.

A study of Tahir et al. (2020) into Malaysian non-financial firms covering a range of sectors for 2005-2018 showed that the independent boards did not have a significant influence on dividend policies. Three empirical findings indicated the existence of a relationship between independent boards and dividend policies in developing countries: A study by Imama et al. (2019) using a sample of 2125 company-years on the Indonesia Stock Exchange for the period 2012-2016 demonstrated that independent boards were positively related to dividend policies in companies that supported Islamic law. Baker, Dewasiri, Yatiwelle Koralalage, \& Azeez (2019), using a sample of 190 companies with 1,330 company-year observations, revealed that corporate governance proxied by independent boards was one of the most significant determinants on dividends in Sri Lanka for the 2010-2016 period. A study by Rajput \& Jhunjhunwala (2019) with a sample of 1,546 Indian firms in 2006-2017 revealed that corporate governance had a significant positive influence on the dividend payout decision and played an important role in determining the dividend payout ratio. The board independent relationships and dividend policy are contradictory in literature. The paper estimated that banks with a larger proportion of independent board of commissioners would usually pay more dividends and a larger payout ratio. Therefore, the research hypotheses are formulated as follow:

H4a: Independent board of commissioners has a positive effect on propensity to pay dividends.

H4b: Independent board of commissioners has a positive effect on the dividend pay-out ratio.

Baker, Dewasiri, Premaratne, and Yatiwelle Koralage (2020) claimed that the audit committee, which included external and independent members and managers, were reluctant to fund projects with a negative net present value (NPV). The audit committee, therefore, had a strong correlation with a theory of free cash flow (Baker et al., 2020). In Indonesia, the Financial Services Authority (POJK) Regulation 55/POJK.04/2005 related to the Establishment and Guidelines for the Work Implementation of the Audit Committee, specified a requirement of at least 3 (three) members of the audit committee. This regulation expectedly improves both company performance and dividend payout policies. Meanwhile, regarding dividend policy, the relationship between audit committee size and dividend payout is demonstrated by the two following empirical studies: First, a study from Elmagrhi et al. (2017) involved a sample of small to mediumsized UK businesses listed on the Alternative Investment Market from 2010 to 2013. The study showed that the relationship between audit committee size and the dividend payout rates was positive and significant. Second, research from Pahi \& Yadav (2019) with a sample of 482 non-financial and non-utility companies in the Indian market from 2006 to 2017. This study found that the audit committee index, including audit committee size, independence, and the frequency of audit committee meetings, has a positive and significant effect on dividend payment policy. Therefore, the proposed hypotheses are as follow:

H5a: Audit committee size has a positive effect on propensity to pay dividends. H5b: Audit committee size has a positive effect on the dividend pay-out ratio. 


\section{METHOD, DATA, AND ANALYSIS}

This paper employs quantitative data from the annual reports of the banking sector listed on the Indonesia Stock Exchange (www.idx.go.id) for the period 2009 to 2019. The data collection included 411 bank-year observations, of which 150 were bank-year observations of dividend distribution and 264 bank-year observations of female boards directors.

\section{Variable Measurement}

Dependent Variable

- The propensity to Pay Dividends (PPD) is a binary variable with a value of 1 (one) for banks that pay dividends, and a value of 0 (zero) for banks that do not pay dividends.

- Dividend Pay-Out Ratio (DPR) is measured by the ratio of dividend per share to earnings per share.

\section{Independent Variable}

- Institutional Ownership (INO) is assessed by the percentage of shares owned by the institution to the total number of shares outstanding

- Board of Directors Size (BDS) determined by the number of members at the board of directors

- Female Board of Directors (FBD), measured by the proportion of the female board members to all members of the board of directors

- Independent Board of Commissioners (INC), determined by the number of members of the independent board of commissioners as proportional to the total members of the board of commissioners

- Audit Committee Size (ACS), determined by the number of audit committee members.

The data in this paper were evaluated using two models of regression: 1) logistic regression, and 2) Ordinary Least Squares (OLS) Regression.

The statistical equations for both models are as follows:

$$
\begin{array}{ll}
\operatorname{Ln} \frac{\text { PPD }}{\text { PPD-1 }}= & \beta_{0}+\beta_{1} \mathrm{INO}+\beta_{2} \mathrm{BDS}+\beta_{3} \mathrm{FBD}+\beta_{4} \mathrm{INC}+\beta_{5} \mathrm{ACS}+\dot{\varepsilon}_{1} \ldots . . .(\text { Model } 1) \\
\mathrm{DPR} & =\beta_{0}+\beta_{1} \mathrm{INO}+\beta_{2} \mathrm{BDS}+\beta_{3} \mathrm{FBD}+\beta_{4} \mathrm{INC}+\beta_{5} \mathrm{ACS}+\dot{\varepsilon}_{2} \ldots \ldots . .(\text { Model } 2)
\end{array}
$$

In which:

$$
\begin{array}{ll}
\operatorname{Ln} \frac{\text { PPD }}{\text { PPD-1 }} & =\log \text { from Propensity to Pay Dividends } \\
\text { DPR } & =\text { Dividend Pay-Out Ratio }
\end{array}
$$


$\beta_{0}=$ Constant value

$\beta_{1}=$ The regression coefficient value of INO

$\beta_{2}=$ The regression coefficient value ofBDS

$\beta_{3}=$ The regression coefficient value of FBD

$\beta_{4}=$ The regression coefficient value of INC

$\beta_{5}=$ The regression coefficient value ofACS

\section{RESULTS}

Table 1 illustrates the maximum, minimum, standard deviation, and the number of observations for all variables examined in this paper.

Table 1. Descriptive Statistics

\begin{tabular}{lrrrrrr}
\hline & DPR & \multicolumn{1}{c}{ INO } & BDS & FBD & INC & ACS \\
\hline Mean & 10.1675 & 78.2571 & 6.5134 & 0.1623 & 0.5673 & 3.8540 \\
Maximum & 81.8100 & 100.0000 & 14 & 0.7500 & 1.0000 & 8 \\
Minimum & 0 & 14.7300 & 3 & 0 & 0.33333 & 2 \\
Std. Dev. & 17.3958 & 15.7968 & 2.5977 & 0.1636 & 0.1099 & 1.0514 \\
Observations & 411 & 411 & 411 & 411 & 411 & 411 \\
\hline
\end{tabular}

Source: The processed data comes from IDX (https:/ / www.idx.co.id) in 2009-2019

Based on Table 1, the average value of the DPR is 10.1675. It shows the dividend per share to earnings and per share ratio for a total of 411 observations. The maximum value of the DPR is 81,810 , while the minimum value by 261 banks which did not distribute dividends is 0.000 , and the standard deviation value is 17.3958 . The average value of INO is $78.2571 \%$. This represents the proportion of institutional investors' bank shares. The maximum value of INO is 100,000. This indicates all shares issued by the bank are owned by institutional investors. The minimum value of INO is $14.7300 \%$, and the standard deviation value is $15.6116 \%$. The mean value of BDS is 6.5134 . This indicates that the bank's board of directors has 6 or 7 members. The maximum value of BDS is 14 people. The minimum value is 3 people. The standard deviation value is 2.5977 / between 2 to 3 people. The average value of FBD for 411 bank-year observations is 0.1623 . It indicates the proportion of female directors to the total members of the board of directors. The maximum value of FBD is 0.750 , while the minimum value is 0.000 . suggesting that the number of banks with no female board directors is 147 banks. The standard deviation value of FBD is 0.1636 . The average value of INC is 0.5673 . It reflects the percentage of members of the independent board of commissioners to the total members of board commissioners for 411 bank-year observations. The maximum value for INC is 1.0000. It means that all members of the board of commissioners are independent. The minimum value for INC is 0.333 . The standard deviation is 0.1099 . The ACS has an average value of 3.8540. It indicates that the average number of members of the bank audit committee is close to 4 people. The maximum value is 8 people, while the minimum value is 2 people, and the standard deviation value is 1.0514 or approximately 1 person. 


\section{Results of Model 1}

Logistic regression analysis used a sample of 411 bank-year observations. The results of the analysis can be found in Table 2 below.

Table 2. Logistic Regression Analysis Results

\begin{tabular}{|c|c|c|c|c|c|}
\hline Independent Variable & Coefficient & Std. Error & z-Statistic & Prob. & Odds Ratio \\
\hline INO & 2.141890 & 0.882262 & 2.427726 & $0.0152^{* *}$ & 8.515 \\
\hline BDS & 2.772655 & 0.743664 & 3.728368 & $0.0002^{* * *}$ & 16.003 \\
\hline FBD & -1.473884 & 0.739634 & -1.992722 & $0.0463^{* *}$ & 0.229 \\
\hline INC & 0.125493 & 1.355705 & 0.092566 & 0.9262 & 1.134 \\
\hline ACS & 1.839451 & 1.075807 & 1.709834 & $0.0873^{*}$ & 6.289 \\
\hline C & -7.644100 & 1.866647 & -4.095096 & $0.0000^{* * *}$ & 0.000 \\
\hline Dependent Variable : PPD & & & & & \\
\hline McFadden R-squared & 0.083281 & \multicolumn{4}{|c|}{ Andrews and Hosmer-Lemeshow (H-L) Tests } \\
\hline LR statistic & 44.92271 & \multicolumn{3}{|c|}{ Andrews Statistic } & 11.8901 \\
\hline Prob(LR statistic) & 0.000000 & \multicolumn{3}{|c|}{ Prob. Chi-Sq(10) } & 0.5033 \\
\hline Percently correctly predicted: & & \multicolumn{3}{|c|}{ H-L Statistic } & 7.3131 \\
\hline Total, \% Correct & 67.6400 & \multicolumn{3}{|c|}{ Prob. Chi-Sq(8) } & 0.2925 \\
\hline
\end{tabular}

Notes: *statistically significant at $10 \%$;* significant at $5 \%$; ${ }^{* * *}$ significant at $1 \%$.

The results of the logistic regression analysis shown in Table 2 shows that the McFadden R-squared value is 0.08328 . The LR statistic is 44.9227 with Prob (LR statistic) is 0.0000 . The total percentage of the predicted value is $67.640 \%$. Andrews Statistic value is 11,890 . The Prob value. Chi-Sq (10) is 0.5033 . The statistical value of $\mathrm{H}-\mathrm{L}$ is 7.3131 . The Prob value. Chi-Sq (8) is 0.2925 . A total percentage of the correctly predicted value is $67.6400 \%$ correct. These values indicate that the logistic regression of the developed model is fit.

\section{Results of Model 2}

The number of banks paying dividends is 150 bank-year observations. However, 25 outliers observation data were discarded. OLS results are presented in Table 3.

Table 3. OLS Multiple Regression Results

\begin{tabular}{lrrrrr}
\hline Independent Variable & Coefficient & Std. Error & t-Statistic & \multicolumn{1}{c}{ Prob. } & \multicolumn{1}{l}{ VIF } \\
\hline INO & -0.611399 & 0.236704 & -2.582966 & $0.0110^{* * *}$ & 1.233254 \\
BDS & -9.317710 & 3.870302 & -2.407489 & $0.0176^{* *}$ & 1.302013 \\
FBD & -3.072963 & 11.02732 & -0.278668 & 0.7810 & 1.196597 \\
INC & 1.307554 & 14.10286 & 0.092715 & 0.9263 & 1.178913 \\
ACS & 17.92259 & 5.430976 & 3.300067 & $0.0013^{* *}$ & 1.326565 \\
C & 72.06552 & 26.33877 & 2.736101 & $0.0072^{* * *}$ & NA \\
Dependent Variable: DPR & & & & \\
\hline
\end{tabular}

R-squared

Adjusted R-squared

F-statistic

Prob(F-statistic)

Jarque-Bera

Probability
0.208595 Heteroskedasticity Test: White

$0.175343 \mathrm{Obs}^{*} \mathrm{R}$-squared

16.75236

6.273108 Prob. Chi-Square(20) 0.6690

0.000034 Breusch-Godfrey Serial Correlation LM Test:

$\mathbf{0 . 4 7 2 2 4 1} \mathrm{Obs}^{*} \mathrm{R}$-squared

4.144678

0.789686 Prob. Chi-Square(2)

0.1259

Notes: ${ }^{* *}$ statistically significant at $5 \%$; ${ }^{* * *}$ statistically significant at $1 \%$. 
Based on table 3, the results of OLS multiple regression have an Adjusted R-squared value of 0.1753 , the F-statistic is 6.2731 with a Probability of 0.0000 . This indicates that the significant impact of the independent variables on the dependent variable is $17,923 \%$. The OLS analysis demonstrates the normal distribution of data through a Jarque-Bera probability value of 0.4722 with a probability value of 0.7897 . OLS analysis indicates VIF values for all independent variables less than 10 . The results of the heteroscedasticity test using the White method yield the Prob value of Chi-Square 0.6690; The Breusch-Godfrey Serial Correlation LM has a value of Prob. Chi-Square 0.1259. This shows that the multiple regression OLS model is free from econometric problems, including multicollinearity, heteroscedasticity, and autocorrelation.

\section{DISCUSSION}

\section{Instutional Ownership and Dividends policy.}

The findings of Model 1 illustrate that institutional ownership has a positive and significant effect on the propensity to pay dividends. These findings suggest that shares issued by banks held by institutional investors have a significantly greater chance of paying dividends. This empirical evidence is consistent with Cheng et al. (2018) who claim that institutional investors will play a more influential role in strengthening corporate monitoring and governance including dividend payout policies if institutional investors continue to increase their stakes in companies. In this regard, institutional investors play an important role in monitoring corporate governance by encouraging management to distribute banks' net income through dividend payments. This empirical evidence is inconsistent with a study by Al-Najjar \& Kilincarslan (2016). They suggested no significant relationship between institutional ownership and the propensity to pay dividends on companies enlisted in the Istanbul Stock Exchange. The findings of model 2 indicate that institutional ownership has a negative and significant effect on the dividend payout ratio. These findings suggest that banks with shares owned by the majority of institutional investors have a lower dividend payout ratio. It is in line with the study by Basri (2019) on 15 state-owned companies listed at the Indonesian Stock Exchange for the period from 2007 to 2013 that showed a negative impact of institutional ownership on the dividend payout ratio. The findings of the relationship between institutional ownership and the dividend pay-out ratio demonstrate the propensity of institutional investors to continue and even raise stock investment in banks.

\section{Corporate Board Size and Dividends policy.}

The results of model 1 demonstrate a positive and significant relationship between Corporate Board size with the propensity to pay dividends. This indicates a higher probability of paying dividends for a bank with larger corporate board size. The larger board size is more successful in monitoring and controlling the opportunistic behavior of management because it offers more knowledge and experience to reduce agency problems and to improve firm performance, i.e. dividend payments (Ntim, Opong, \& Danbolt, 2015). This finding is in line with Tahir et al. (2020) on Malaysian non-financial companies, suggesting that the board size positively effects dividend policies. Model 2 findings reveal that the board of directors size has a negative and significant effect on the dividend payout ratio. The findings of this analysis show that banks with larger board size significantly have a lower dividend payout ratio. It is consistent with research by Sanan (2019) in India which suggested that board size negatively affect dividend policies. However, the result of model 2 is inconsistent with a study by Elmagrhi et al. (2017) 
suggesting that the board size is positively related to dividend payout ratio in UK SME companies. The Empirical data suggests that first, a larger board size of the bank shows an improved performance to shareholders by dividend payout; Second, banks should promote internal funds (retained earnings) to financially support their potential growth in the future.

\section{Female Board of Director and Dividends policy.}

The findings of Model 1 suggest a negative and significant effect of the female board of directors on the propensity to pay dividends. It means that banks with a more female board of directors are significantly less likely to pay dividends. This empirical evidence confirms previous research by Saeed \& Sameer (2017) and Sanan (2019) that the proportion of female directors on the board has a negative and significant effect on the propensity to pay dividend since the female board of directors tend to be more cautious and risk-averse. Dividend payment decisions are inseparably linked to decisions on the capital structure of the company. Research by Elmagrhi et al. (2017) in the United Kingdom shows that the female board of directors has a negative effect on the capital structure of the company. The inclusion of female board directors allows company to reduce the debt ratio, although the need for additional internal funding such as retained earnings is priority. Therefore, the probability of paying dividends is considerably smaller for banks with a greater proportion of female board of director. Even the findings of Model 2 suggest that they would not significantly influence the dividend payout ratio. These findings suggest that the magnitude of female directors on the board at banks is not related to the dividend payout ratio. The findings of this study are consistent with a study by McGuinness et al. (2015) that no significant relationship exists between female directors and dividend payout rates in China. However, the results of this study do not support a study by Benjamin \& Biswas (2019) who analyzed the Bloomberg Firms S\&P 1500. They indicated that gender composition had a favorable influence on the dividend payout rate.

\section{Independent Board of Commissioners and Dividends Policy.}

The findings of Model 1 show that the independent board of commissioner has a positive effect on the propensity to pay dividends, except this effect is not statistically significant. These findings suggest that the percentage of independent members on the board of commissioners at banks does not impact the propensity to pay dividends. Model 2 findings indicate that the independent board of commissioners has a positive impact on the dividend payout ratio. However, as was the case in model 1 . This effect is not statistically significant. These findings suggest that there is no relationship between dividend payout ratio and proportion of independent members at the board of commissioner. As suggested by Sener \& Akben Selcuk (2019) and Tahir et al. (2020), the findings of this study are theoretically in line with the assumptions of the substitution hypothesis which states that companies with good governance practices measured by independent board size are less likely to pay dividends. It has something to do with the fact that both board independence and dividend payments are substitutes for reducing agency costs. This finding is in line with a study of Elmagrhi et al. (2017) for The United Kingdom's SMEs that demonstrated no significant effect between independent boards with dividend payout rates. However, the findings of the study are inconsistent with a study from Imamah et al. (2019). They state that independent boards, in companies abiding by Islamic law in Indonesia are positively related to dividend policies. The study 
findings are not aligned with a study of Baker et al. (2019), who argued that the independent board is one of Sri Lanka's most significant determinants of dividends.

\section{Audit Committee Size and Dividends Policy.}

The finding of Model 1 demonstrates a value of 0.0873 , meaning that the audit committee size has a positive impact on the propensity to pay dividends. This suggests a major positive impact at the $10 \%$ level. Companies with a larger audit committee size $(10$ $\%)$ have a significantly higher propensity to pay dividends. Thus, the results of the study are consistent with previous research conducted by Pahi \& Yadav (2019) in India. They prove that the audit committee index, one of which is proxied with audit committee size, has a positive and significant effect on dividend payout policy. Meanwhile, the finding of Model 2 shows that a positive and significant effect on the dividend payout ratio is affected by the audit committee size. It suggests that banks with larger audit committee size are higher in the propensity to pay dividends with a higher ratio. The results of this study are in line with the prediction that larger audit committees lead to increased managerial monitoring. Thus, it helps to minimize agency problems by encouraging management to allocate surplus cash flow in the form of dividends to shareholders within the condition in which projects with a positive NPV does not occur. These findings support POJK No 55/POJK 04/2005 on the Establishment and Guidelines for the Work Implementation of the Audit Committee, which state that there should be at least 3 (three) members of the Audit Committee. This empirical evidence is based on a study by Elmagrhi et al. (2017) that found a positive and significant relationship between dividend payments ratio and audit committee size.

\section{CONCLUSION, LIMITATIONS, AND SUGGESTIONS}

Based on the findings of model 1 and model 2, the conclusions in this paper are as follows. First, banks with shares majorly owned by institutional investors have a higher propensity to pay dividends. Moreover, the higher the institutional ownership, the lower the pay-out dividend ratio. Second, banks with a larger board size have a significantly greater propensity to pay dividends. Moreover, the larger the size of the board of directors, the lower the payout dividend ratio. Third, banks with a higher percentage of the female board of directors have a slightly lower propensity to pay dividends with no major impact on the dividend payout ratio. In addition, there is no major gender effect on the Board of Directors that pays dividends. Fourth, the audit committee size has a big influence on the probability of dividend payments. Moreover, the larger the audit committee size, the larger the payout ratio of dividends distributed by the bank. Fifth, there is no substantial effect of an independent board of commissioners on the propensity to pay dividends or the dividend payout ratio. This paper has several shortcomings. One of which is the limited scope only from the banking industry of the Indonesian Stock Exchange. Meanwhile, corporate governance is the only predictor in analyzing the propensity to pay dividends and dividend payout ratios. In this paper, Corporate governance includes five variables: institutional ownership, the board of directors' size, the female board of directors, audit committee size, and independent board of commissioners. It is also recommended to include other company groups or industries in a future study. When analyzing proxy variables of corporate governance, it is recommended to include share ownership by foreign institutions, government, and management. CEO duality, board activity, and competency may also be used as the 
corporate governance proxy variables. Besides, macroeconomic, company and bankspecific factors can be used as dividend policy predictors. The findings of the study provide suggestions for investors and potential investors: First, to invest in a bank with a larger board size with shares owned by a larger percentage of institutional investors; Second, to invest funds in a bank with a larger audit committee size to gain a higher propensity to pay a dividend with a higher dividend payout ratio.

\section{REFERENCE}

Al-Najjar, B., \& Kilincarslan, E. (2016). The effect of ownership structure on dividend policy: evidence from Turkey. Corporate Governance: The International Journal of Business in Society, 16(1), 135-161. https://doi.org/10.1108/CG-09-2015-0129

Al-Najjar, B., \& Kilincarslan, E. (2019). What do we know about the dividend puzzle? - A literature survey. International Journal of Managerial Finance, 15(2), 205-235. https:/ / doi.org/10.1108/IJMF-03-2018-0090

Almeida, T. A., Morais, C. R. F. de, \& Coelho, A. C. (2020). Gender diversity, governance and dividend policy in Brazil. Revista de Gestão, 27(2), 189-205. https://doi.org/10.1108/rege-03-2019-0041

Atanassov, J., \& Mandell, A. J. (2018). Corporate governance and dividend policy: Evidence of tunneling from master limited partnerships. Journal of Corporate Finance, 53, 106-132. https://doi.org/10.1016/j.jcorpfin.2018.10.004

Baker, H. K., Dewasiri, N. J., Premaratne, S. P., \& Yatiwelle Koralalage, W. (2020). Corporate governance and dividend policy in Sri Lankan firms: a data triangulation approach. Qualitative Research in Financial Markets, 12(4), 543-560. https:// doi.org/10.1108/QRFM-11-2019-0134

Baker, H. K., Dewasiri, N. J., Yatiwelle Koralalage, W. B., \& Azeez, A. A. (2019). Dividend policy determinants of Sri Lankan firms: a triangulation approach. Managerial Finance, 45(1), 2-20. https:// doi.org/10.1108/MF-03-2018-0096

Baker, H. K., \& Jabbouri, I. (2017). How Moroccan Institutional Investors View Dividend Policy. Managerial Finance, 43(12), 1332-1347.

Baker, H. K., Kapoor, S., \& Jabbouri, I. (2018). Institutional perspectives of dividend policy in India. Qualitative Research in Financial Markets, 10(3), 324-342. https://doi.org/10.1108/QRFM-07-2017-0067

Balachandran, B., Khan, A., Mather, P., \& Theobald, M. (2019). Insider ownership and dividend policy in an imputation tax environment. Journal of Corporate Finance, 54, 153-167. https://doi.org/10.1016/j.jcorpfin.2017.01.014

Basri, H. (2019). Assessing determinants of dividend policy of the government-owned companies in Indonesia. International Journal of Law and Management, 61(5-6), 530541. https://doi.org/10.1108/IJLMA-09-2017-0215

Benjamin, S. J., \& Biswas, P. (2019). Board gender composition, dividend policy and COD: the implications of CEO duality. Accounting Research Journal, 32(3), 454-476. https://doi.org/10.1108/ARJ-02-2018-0035 
Bilel, H. (2020). Does entrenchment of managers affect entrepreneurial dividend decision and investor sentiment? Asia Pacific Journal of Innovation and Entrepreneurship, aheadof-p(ahead-of-print), 275-288. https://doi.org/10.1108/apjie-10-2019-0072

Black, F. (1976). The Dividend Puzzle. The Journal of Portfolio Management, 2(2), 5-8. https://doi.org/10.3905/jpm.1976.408558

Brennan, M. J. (1970). Taxes, Market Valuation and Corporate Financial Policy. National Tax Association, 23(4), 417-427. https://doi.org/10.1057/978-1-349-95988-4_100273

Budagaga, A. R. (2020). Determinants of banks' dividend payment decisions: evidence from MENA countries. International Journal of Islamic and Middle Eastern Finance and Management, 13(5), 847-871. https:// doi.org/10.1108/IMEFM-09-2019-0404

Byoun, S., Chang, K., \& Kim, Y. S. (2016). Does Corporate Board Diversity Affect Corporate Payout Policy? Asia-Pacific Journal of Financial Studies, 45(1), 48-101. https://doi.org/10.1111/ajfs.12119

Chang, K., Kang, E., \& Li, Y. (2016). Effect of institutional ownership on dividends: An agency-theory-based analysis. Journal of Business Research, 69(7), 2551-2559. https://doi.org/10.1016/j.jbusres.2015.10.088

Chen, J., Leung, W. S., \& Goergen, M. (2017). The impact of board gender composition on dividend payouts. Journal of Corporate Finance, 43, 86-105. https://doi.org/10.1016/j.jcorpfin.2017.01.001

Cheng, J.-C., Lin, F.-C., \& Tung, T.-H. (2018). The Effect of Institutional Ownership Stability on Cash Dividend Policy: Evidence from Taiwan. 207-222. https:/ / doi.org/10.1108/s2514-465020180000006006

Elmagrhi, M. H., Ntim, C. G., Crossley, R. M., Malagila, J. K., Fosu, S., \& Vu, T. V. (2017). Corporate governance and dividend pay-out policy in UK listed SMEs: The effects of corporate board characteristics. International Journal of Accounting and Information Management, 25(4), 459-483. https:/ / doi.org/10.1108/IJAIM-02-2017-0020

Firth, M., Gao, J., Shen, J., \& Zhang, Y. (2016). Institutional stock ownership and firms' cash dividend policies: Evidence from China. Journal of Banking and Finance, 65, 91107. https://doi.org/10.1016/j.jbankfin.2016.01.009

Flavin, T., \& O'Connor, T. (2017). Reputation building and the lifecycle model of dividends. Pacific Basin Finance Journal, 46(April), 177-190. https:/ / doi.org/10.1016/j.pacfin.2017.09.006

Gruber, E. J. E. and M. J. (1970). Marginal Stockholder Tax Rates and the Clientele Effect. The Review of Economics and Statistics, 52(1), 68-74. Retrieved from http://www.jstor.org/stable/1927599

Gyapong, E., Ahmed, A., Ntim, C. G., \& Nadeem, M. (2019). Board gender diversity and dividend policy in Australian listed firms: the effect of ownership concentration. Asia Pacific Journal of Management, (June). https:/ / doi.org/10.1007/s10490-019-09672-2

Imamah, N., Lin, T. J., Suhadak, Handayani, S. R., \& Hung, J. H. (2019). Islamic law, corporate governance, growth opportunities and dividend policy in Indonesia stock 
market. Pacific Basin Finance Journal, 55(December 2017), 110-126. https://doi.org/10.1016/j.pacfin.2019.03.008

Jabbouri, H. K. B. I. (2016). How Moroccan managers view dividend policy. Managerial Finance, 34(1), 1-5.

Jensen, M. C. (1986). Agency costs of free cash flow, corporate finance, and takeovers. American Economic Association, 36(2), 323-329. https://doi.org/10.1017/cbo9780511609435.005

Kent Baker, H., Kilincarslan, E., \& Arsal, A. H. (2018). Dividend policy in Turkey: Survey evidence from Borsa Istanbul firms. Global Finance Journal, 35, 43-57. https://doi.org/10.1016/j.gfj.2017.04.002

Kulathunga, K. M. K. N. ., Weerasinghe, W. D. J. ., \& Jayarathne, J. A. . (2017). Corporate governance and dividend policy: A study of listed hotels and restaurant companies in Sri Lanka. International Journal of Scientific Research and Innovative Technology, 4(2), 64-81.

McGuinness, P. B., Lam, K. C. K., \& Vieito, J. P. (2015). Gender and other major board characteristics in China: Explaining corporate dividend policy and governance. Asia Pacific Journal of Management, 32(4), 989-1038. https://doi.org/10.1007/s10490-0159443-y

Mehdi, M., Sahut, J.-M., \& Teulon, F. (2017). Do corporate governance and ownership structure impact dividend policy in emerging market during financial crisis? Journal of Applied Accounting Research, 18(3), 274-297.

Meza, N., Báez, A., Rodriguez, J., \& Toledo, W. (2020). The dividend signaling hypothesis and the corporate life cycle. Managerial Finance. https://doi.org/10.1108/MF-102019-0512

Ntim, C. G., Opong, K. K., \& Danbolt, J. (2015). Board size, corporate regulations and firm valuation in an emerging market: a simultaneous equation approach. International Review of Applied Economics, 29(2), 194-220. https:// doi.org/10.1080/02692171.2014.983048

Pahi, D., \& Yadav, I. S. (2019). Does corporate governance affect dividend policy in India? Firm-level evidence from new indices. Managerial Finance, 45(9), 1219-1238. https://doi.org/10.1108/MF-01-2019-0030

Pruitt, S. W., \& Gitman, L. J. (1991). The Interactions between the Investment, Financing, and Dividend Decisions of Major U.S. Firms. Financial Review, 26(3), 409-430. https://doi.org/10.1111/j.1540-6288.1991.tb00388.x

Pucheta-Martínez, M. C., \& Bel-Oms, I. (2016). The board of directors and dividend policy: The effect of gender diversity. Industrial and Corporate Change, 25(3), 523-547. https://doi.org/10.1093/icc/dtv040

Rajput, M., \& Jhunjhunwala, S. (2019). Corporate governance and payout policy: evidence from India. Corporate Governance (Bingley), 19(5), 1117-1132. https://doi.org/10.1108/CG-07-2018-0258 
Ranajee, R., Pathak, R., \& Saxena, A. (2018). To pay or not to pay: what matters the most for dividend payments? International Journal of Managerial Finance, 14(2), 230-244. https://doi.org/10.1108/IJMF-07-2017-0144

Rozeff, M. S. (1982). Growth, Beta and Agency Costs As Determinants of Dividend Payout Ratios. Journal of Financial Research, 5(3), 249-259. https://doi.org/10.1111/j.14756803.1982.tb00299.x

Saeed, A., \& Sameer, M. (2017). Impact of board gender diversity on dividend payments: Evidence from some emerging economies. International Business Review, 26(6), 11001113. https://doi.org/10.1016/j.ibusrev.2017.04.005

Sanan, N. K. (2019). Impact of board characteristics on firm dividends: evidence from India. Corporate Governance (Bingley), 19(6), 1204-1215. https://doi.org/10.1108/CG12-2018-0383

Sener, P., \& Akben Selcuk, E. (2019). Family involvement, corporate governance and dividends in Turkey. Managerial Finance, 45(5), 602-621. https:// doi.org/10.1108/MF-01-2018-0011

Shamsabadi, H. A., Min, B. S., \& Chung, R. (2016). Corporate governance and dividend strategy: lessons from Australia. International Journal of Managerial Finance, 12(5), 583610. https://doi.org/10.1108/IJMF-08-2015-0156

Singla, H. K., \& Samanta, P. K. (2019). Determinants of dividend payout of construction companies: a panel data analysis. Journal of Financial Management of Property and Construction, 24(1), 19-38. https:// doi.org/10.1108/JFMPC-06-2018-0030

Tahir, H., Masri, R., \& Rahman, M. M. (2020). Impact of board attributes on the firm dividend payout policy: evidence from Malaysia. Corporate Governance (Bingley), 20(5), 919-937. https://doi.org/10.1108/CG-03-2020-0091

Trihermanto, F., \& Nainggolan, Y. A. (2018). Corporate life cycle, CSR, and dividend policy: empirical evidence of Indonesian listed firms. Social Responsibility Journal, 16(2), 159-178. https:/ / doi.org/10.1108/SRJ-09-2017-0186 